\title{
Assessing climate impacts on English economic growth (1645-1740): an econometric approach
}

\author{
José Luis Martínez-González ${ }^{1} \bullet$ Jordi Suriñach $^{1} \bullet$ Gabriel Jover $^{3} \bullet$ \\ Javier Martín-Vide ${ }^{2}$ Mariano Barriendos-Vallvé $^{2} \bullet$ Enric Tello $^{1}$
}

\begin{abstract}
British pre-industrial economic growth has traditionally been analysed from the Malthusian point of view and other more optimistic approaches, but in many cases ignoring environmental factors. This article explores the inclusion of the climate in this general debate, focusing on one of the colder periods of the last five hundred years, known as the Maunder Minimum. The provisional results suggest that climate change and the resulting adaptations may have influenced the start of the English Agricultural Revolution, the Energy Transition and the European Divergence. However, from an econometric point of view these results are not fully conclusive, making it necessary to continue working with better primary sources and other alternative methodologies.
\end{abstract}

Keywords: Economic growth, England, Early Modern Age, climate impacts, agriculture, energy, work.

José Luis Martínez-González (jlmartinez.economic.history@ gmail.com) • Jordi Suriñach - Enric Tello

${ }^{1}$ Faculty of Economics and Business, 690 Diagonal Avenue, 08034 Barcelona, Spain

Javier Martín-Vide • Mariano Barriendos-Vallvé

${ }^{2}$ Group of Climatology, University of Barcelona, Montalegre 6, 08001, Barcelona, Spain

Gabriel Jover

${ }^{3}$ Department of Economics, University of Girona, Montilivi Campus, 17003 Girona, Spain 


\section{Introduction}

The threat and challenges climate change pose to the current model of social and economic development have aroused growing interest among social science researchers and public institutions, as well as some convergence in its diagnosis and future consequences (Dell et al. 2014). As these same studies recognize, the only laboratory available to perceive humanity's capacity to adapt to these changes is historical research (Parry 1978). Within this framework, one of the historical climate episodes that has aroused greatest interest among climatologists and historians has been the Little Ice Age (LIA, 1350-1850), as recently summarized by Camenisch and Rohr (2018), and in particular the period known as the Maunder Minimum (1645-1715). Some historians have argued that the marked worsening of climatic conditions in the medieval period (Campbell 2010, 2016) and in the seventeenth century (Parker 2013; White 2014) had a significant impact on the world's population and economy. However, there is no unanimous scientific agreement regarding the intensity of these climate disturbances or their impact on human activities. Even more, Kelly and O'Grada (2014) have questioned these effects: in the very long term, the series of temperatures are stationary and do not have drastic breakpoints, although a correspondence has been observed between temperatures and volcanic activity, to which some relevance is attributed when explaining the decrease in temperatures (Owen et al. 2017) among other hypotheses (Koch et al. 2019).

This work is based on well-established assumptions in the socio-ecological literature, namely that in pre-industrial societies almost all of the energy that was consumed depended on the flow of solar radiation and on the management of organic converters that transformed that primary energy into food and fuel for rural and urban communities (Wrigley 2010; Smil 2017; Kander et al. 2013). Under these circumstances we can expect that strong climatic fluctuations in the short and medium term may have played a relevant role in causing or hindering the changes that generally took place in the aforementioned communities (Overton 1989). In the same vein, we can assume that these impacts would have been particularly intense during extreme climatic periods (Cullen 2010; White 2014; Campbell 2016). Therefore, excluding climatic factors from the development models 
used to explain the historical paths of pre-industrial organic societies may reduce their explanatory capacity.

The aim of this article is to evaluate the effects of the climatic disturbances that took place during the Maunder Minimum on agriculture, the population, the energy transition and the economy at large. The analysis will be focused on those socio-ecological processes in which climatic interferences on soil management (agriculture) and the well-being of individuals (energy availability) can be more easily approached from a logical and quantitative perspective. The study will distinguish between two periods: the first, from 1645 to 1700 , that was especially cold and wet and climatic disturbances were more intense; and the second, warmer subsequent period (1700-1740). The study will focus on England for two reasons. Firstly, because it has played a central role in the debates on the relationship between climate and economic changes during that period (Hoyle 2018). And secondly, because we can count on economic and climatic instrumental series to carry out this exercise.

The article is divided into the following sections. The first deals with the main historiographical and scientific discussions on the relationship between climate change and socioeconomic conditions. The second describes the sources, the model and methodology used. In the third we present and discuss the results. And finally, the conclusion considers the strengths and weaknesses of the available econometric evidence on the relationship between climate and economic changes during the Maunder Minimum.

\section{Climate and economic changes in England between 1650 and 1750: historical and current evidence}

The period 1650-1750 has been considered the starting point of the economic transformation towards the Industrial Revolution in England (Clark 2005; Broadberry et al. 2015; Crafts and Mills 2017). Several changes allowed that jump to be made: an increase in agricultural productivity, commercial expansion, and the growth of London urban population and those of other cities (Jones 1965; De Vries 1984; Wrigley 1985; Allen 2009). These transformations were achieved via the intensification of human work 
and energy consumption (De Vries 1994, 2008; Warde 2007; Malanima 2015). However, a whole historiographical tradition has stressed that these economic improvements took place in the second half of the seventeenth century under adverse climatic conditions. Climate studies have shown that in England, and all over Europe, average annual temperatures decreased and their interannual and seasonal variability increased throughout the period 1645-1715, while average rainfall also increased, particularly in the warmer months (Collins et alia 2002; Luterbacher et al. 2001; Brázdil et al. 2010; Parker 2013). These phenomena coincided with prolonged minimum solar activity, a period known as the Maunder Minimum (Eddy 1976), an increase in volcanic activity (Owens et al. 2017) and a decrease in the Carbon global concentration in the atmosphere (Koch et al. 2019).

Studies on the relationship between climate and agriculture have yielded the most relevant results on the subject. They have shown that a cooler, wetter climate and a greater seasonal and interannual variability had relevant effects on crops and livestock production (Jones 1964; Appleby 1979, 1980; Overton 1989, 1996; Cullen 2010; Hoyle 2013). This involved not only direct impacts on crops deriving from extreme meteorological variations (frosts, storms and excess rainfall; see Jones 1965; Appleby 1978; Cullen 2010), but also agro-climatic changes that affected harvests in a longer term. On the one hand, less solar radiation and other atmospheric phenomena (such as a greater number of cloudy days reinforced by volcanic eruptions) combined with lower temperatures and led to a shortening of the plant growing season, and to a lower soil microbial activity. On the other hand, an increase in summer rainfall led to more leaching processes of soil nutrients (nitrogen, phosphorus and potassium), altered the acidity of soils, and increased pest infestation of crops (Camenisch et al. 2016; Tello et al. 2017). This type of relationships, of which there is some historical evidence for the period studied, has also been observed in modern advanced agriculture that is expected to be less weather dependent (Dell et al. 2012, 2014; Powell et al. 2016).

However, a number of studies have also suggested that the worsening of the climate may have induced innovation in soil and plant management (Overton 1989; Hoyle 2013). Experimentation with drainage systems, manure fertilization and rotation of grains with legumes, as well as the introduction of new crops or species more resistant to cold or 
moisture have all been presented as evidences of adaptive behaviour. These studies have argued that although such practices had little effect on the increase on wheat yields during the second half of the seventeenth century (in contrast with other cereals such as barley), they did contribute to the further increase in yields when the climatic conditions improved in the first half of the $18^{\text {th }}$ century (Michaelowa 2001; Tello et al. 2017). This impact of the hardening of the climate has been recorded in other Atlantic regions, particularly the cultivation of cereals in Central Europe (Holopainen and Helana 2009; Pei, Zhang, Lee and Li 2016; Zwiter 2015).

Climate change can also help explain one of the paradoxes of that age: the increase in the rate of urbanization in a period of decelerated population growth (Wrigley 1985). The effects of climate on demography were not necessarily direct, as they are mediated by other environmental and food factors, as numerous studies in today's advanced societies have highlighted. Outside the comfort zone of the human body (between 18 and $22^{\circ} \mathrm{C}$ ) there are cardiovascular, respiratory and digestive effects and other physiological changes such as cerebrovascular problems, ergotism and fungal diseases that lead to increased mortality among the more vulnerable social groups (Deschênes and Greenstone 2012; Braga et al. 2001, 2002; Parsons 2014; Heal and Park 2016; Camenisch et al. 2016; Pillay and van den Bergh 2016). As current biomedical studies show, decreases in temperatures continue to have more drastic effects on health than increases (Keatinge et al. 2000; Martens 1998).

Historical research on England has also observed that a decrease in temperatures may have contributed to an increase in mortality, due to the increased presence of respiratory and cardiovascular diseases, a fertility decrease (due to increased mortality rate among pregnant women and foetal infections), and a drop in the nuptiality rate (Wrigley and Schofield 1981; Galloway 1985, 1986, 1994; Houston 1996). It has been observed in other geographical areas and periods that certain epidemics spread more easily when there is a decrease in temperature and an increase in humidity (Stenseth et al. 2006; Alfani and Murphy 2017; Campbell 2010). Thomas Sydenham (1676), considered the father of English medicine, linked weather and diseases, year per year. Recently, new anthropometric and biomedical studies have abounded in the same direction (Koepke and 
Baten 2005; Almond and Currie 2011; Graff Zivin and Shrades 2015; Heal and Park 2016).

Might this hardening of the climate have affected people's ability to work and comfort? The availability of work depended, in addition to economic and social factors, on the strength of the labour force in its most physical sense: the amount of energy that individuals should spend to work and reproduce, after discounting the energy required by the vital functions of the organism. Current studies show a 17 to 50 percent increase in energy expenditure with cold temperature (Mäkinen 2006; Claessens van Ooijen et al. 2006; Ocobock 2014, 2016). Thus, in order to maintain their work capacities during a period of colder temperatures in a wetter environment, people would have to consume more foods and heat (Malanima 2015).

Current researches have shown that, ceteris paribus, thermal stress during a temperature decrease can affect workers in at least two ways: through direct physical effects or through psychological discomfort, which cause a change in effort per hour and reduce short-term labour productivity (Graff Zivin and Neidell 2014; Seppanen et al. 2006; Heal and Park 2016; Pillay and van den Bergh 2016). These results allow us to recover the hypothesis raised by British historian Donald C. Coleman many years ago (Coleman 1956): might the decrease in temperatures have affected the labour force availability and labour productivity during the seventeenth century (Jones 1965; Finzi 1986, 1998)? Did this climate pressure end up affecting the remuneration of labour? In addition, recent studies have suggested that the decrease in temperatures may have played a role in the energy transition from firewood and charcoal to coal in England. All in all, the colder temperatures may have increase demand for endosomatic (food intake) as well as exosomatic (fuel) energy carriers (Flinn 1985; Hatcher 2003; Warde 2007; Kander et al. 2013; Malanima 2015).

Some authors have gone further by suggesting that the variation in aggregate production may have been due to the inclement weather. In areas where temperatures are persistently low, there is an increase in energy expenditure in both the agricultural and manufacturing sectors and at home. The hardening of climatic conditions can even induce an increase in wages or the substitution of labour for capital in the medium term (Park and Heal 2013; 
Graff et al. 2014, 2015, 2016). Currently, robust evidence has been provided regarding the effect of an increase in temperatures on the reduction in economic growth rates due to decreased productivity in warmer countries (Dell et al. 2012). An opposite effect (increased productivity) has been found in temperate countries that experience significant drops in temperature (Heal and Park 2016). Many cross-sectional analyses have found strong evidence of a negative relationship between temperatures and economic activity in contemporary economies (Dell et al. 2014). We have good reason to assume that this relationship should have been much stronger in pre-industrial organic societies (Camenisch and Rohr 2018).

Based on these historical or current evidences, our aim is to explore this set of probable relationships between climate change and economic performance in England during the Maunder Minimum, using the available data to perform econometric tests.

\section{Sources and methods}

The greatest problem facing empirical analysis is the scarcity and poor quality of data. Most available sources are estimates or indirect approximations from which relatively homogenous series of the relevant variables have been constructed by historians. Therefore, there is a high risk of error due to lack of reliable and independent exogenous variables to complete models, as well as possible endogeneity problems. In addition, when trends or variations in climatic series are studied in Climatology, they must be homogeneous. That is, they should only reflect the natural behaviour of the observed variable, without external interferences to the phenomenon maintained over time.

Therefore, the results must be considered with caution, taking into consideration that this is only an empirical exploration using a multiple linear regression approach to the available metadata. Econometrics is used primarily to find evidence of short-term impacts. No panel techniques have been used, because there are not enough data (or of enough quality) to carry out a cross-sectional and dynamic analysis. It must also be taken into account that climate is an abstract and complex concept, in which the conjunction of elements is more important than their individual consideration. Climatic variables can be combined according to different functional relationships, and not necessarily linear ones, 
with different weights in different periods. This makes our econometric analysis even more difficult in a historical period without reliable statistics.

Although pre-instrumental climatic data are scarce, we do have series of temperatures and rainfall, as well as other exogenous indicators that affect climate and life, such as solar radiation and volcanic dust. There is a series of monthly temperatures for the Midlands that begin in 1659, known as 'Central England Temperature' or CET (Manley 1974). CET is a very valuable series of temperature, the longest in existence. For solar radiation and volcanic activity, we can refer to the series provided by Mann et al. (2000). Although there are no serial records of humidity or rainfall for the seventeenth century, some recent research is beginning to shed light on this issue through the reconstruction of historical series of rainfall between May and August (summer) in southern England (Rinne et al. 2013) , between March and July (spring-summer) in the east of England (Cooper et al. 2012), and between March and July (spring-summer) in southern and central England (Wilson et al. 2012). At this point, it is important to highlight the interdependence between temperature and rainfall. The correlation between the CET temperatures and the series of rainfall in England and Wales during the summer varies according to the period analysed, but the warmer the climate, the drier it is. It is unlikely that a relationship that persists throughout the twentieth century does not apply to the seventeenth and eighteenth centuries. Although the multicollinearity statistics do not show any cause for concern it is reasonable to suggest that there will be some correlation between rainfall and temperature at the seasonal level and that this should be borne in mind.

A series of annual wheat production (in volume and weight) has been obtained for English and Wales from a new estimate of the physical product using the King-Davenant approach. The series fits very well with the trends and oscillations shown by other local and shorter series constructed from probate inventories and farm accounts (MartínezGonzález 2016; Martínez-González et al. 2019). Annual demographic indicators (population, births, marriages and deaths) are taken from E. A. Wrigley (Wrigley et al. 1981). 
Real GDP at constant prices is taken from Broadberry et al. (2015), and GDP per capita is obtained by dividing the former by the population. Expenditure on coal consumption is calculated by multiplying the price of coal per tonne (Clark 2004, 2005, 2007) by its consumption (Warde 2007), after converting petajoules to equivalent tonnes of coal. Shipments of coal from Newcastle are taken from the mining accounts (Hatcher 1993), although the series only goes up to 1700 . According to Hatcher, 75 per cent of these shipments were to London. According to Broadberry et al. (2015), these shipments are also an excellent indicator of the increase in coal consumption in England. Corn Bounties is a series of dummy variables with a value of 1 in the years when public export subsidies and high import tariffs were applied, and a value of 0 when they were not applied during years of greatest scarcity (Ormrod 1985). The labour productivity for wheat cultivation is a physical value, which is obtained by dividing the gross production of wheat by the male labour force, calculated above. Total male agricultural productivity is the quotient between the real agricultural GDP (Broadberry et al. 2015) and the male labour force.

All the series of daily wages (for agricultural workers, craftsmen and construction workers) and grain prices (wheat, barley) are taken from Gregory Clark (2004, 2005, 2007). A proxy of real agricultural wages is obtained by relating daily agricultural wages to wheat prices. We use daily wages and not annual salaries, although it should be noted that the former only comprised part of the labour market. A significant proportion of agricultural workers received annual salaries, which included board and lodging (Kussmaul 1981). The demand for agricultural work shifted between both markets, and even required reserves of female and child labour during periods of intense demand, especially during agricultural labour intensification processes. However, temporary fluctuations are more likely to affect daily wages (the casual work market) than annual salaries.

The econometric method applied is presented in two parts: climate impacts on economic activity and society $(i)$; and on the aggregate economic growth (ii). First, we try to find possible indications of biophysical effects on cropland production (agriculture), population growth (demography) and energy consumption ( $i$ ); and then on wages and the economic growth as a whole (ii). We define 'climate impacts' in the following sense: "climate change operates indirectly through multiple pathways, to affect economic 
activity and human well-being. These pathways include the biophysical effects of changes in temperature, precipitation on crop yields, human health, and plant pest and diseases" (Feola et al. 2014).

We use the same impact equation that is presented in modern literature (Dell et al. 2014), with the following general formula:

$$
Y_{t}=\alpha+\beta C_{t}+\gamma X_{t}
$$

Where $\boldsymbol{Y}_{\boldsymbol{t}}$ is the impact variable to be studied. In this paper the series used are either in physical terms (output of wheat, physical labour productivity, population, birth rate, mortality rate, marriage rate) or in economic value (coal prices, coal expenditure, economic productivity, daily wages of agricultural workers, craftsmen and construction workers, GDP). In addition, $\boldsymbol{C}_{\boldsymbol{t}}$ is the set of climatic variables (temperatures, rainfall) and other impact factors that affect the climate and all life processes (volcanic dust, solar radiation), and $\boldsymbol{X}_{\boldsymbol{t}}$ could represent other possible explanatory variables that would come into play.

\section{Results}

\subsection{Impacts on agriculture, population growth, and energy consumption}

Table 1 (see supplementary material) shows two multiple regression models between production (dependent variable) and a group of independent variables (climatic and economic). On the whole, a statistically significant relationship is detected between climate and gross wheat production or barley price, which explains between 46 and 72 percent of the behaviour of the endogenous variable. The Ramsey reset test indicates that the linear relationship is the best specification of the model with respect to squared or cubed temperatures, or both exponents. In the first model, a $1^{\circ} \mathrm{C}$ drop in temperature and a $50 \mathrm{~mm}$ increase in summer rainfall generates an approximate average fall in wheat production of -3.5 million bushels. This combination of cold and wet weather was very common between 1659 and 1700: 38 years out of 41 had temperatures lower that the 
average ones in the first part of the $20^{\text {th }}$ century. That is, it was a much colder and wetter period than the contemporary one before the beginning of current global warming (Figure 1). The impacts occurred during the year of the harvest considered, and in following ones. This suggests that the climate affected wheat harvests in two ways: through the direct effects of temperatures, rainfall, and storms, and through indirect effects on the rate of Nitrogen (N) mineralization and accumulation of organic matter (Tello et al. 2017). Although the lagged variables suggest the impacts had an interannual effect, the correlograms show that all of the series in Model 1 are stationary, meaning that the observed shocks were short-term. The absence of very persistent effects could suggest the existence of adaptations, although this could also be due to a more statistical reason: since the variables are not cointegrated, we cannot establish an error correction model.

Unlike wheat, in barley we do not have a series of annual production in bushels. According to Broadberry et al. (2015), barley production rose from 33.5 to 35.5 million bushels between 1650 and 1700. Barley had different characteristics from wheat. Firstly, it was a substitute for wheat in times of bad harvests (Appleby 1979, 1980; Hoyle, 2013), so its price also depended on how the wheat was produced. Secondly,-barley was a spring cereal, which made it immune to the cold of winter, but it was sensitive to inclement weather during the harvest and summer rains (such as wheat, or a bit less). Excessive humidity also damaged the stored grain. Thirdly, demand for beer was a key factor in barley production. In 1700, 70 percent of the total was for brewing (Broadberry et al. 2015). Fourthly, it was also used to feed livestock. There is no doubt that the issue of barley deserves more research. However, in a first approximation (Table 1, Model 2), we find that wheat production, temperature and the price of beer are very significant variables for the price of barley. The price of barley increased if wheat production declined (as it was a substitute cereal), if beer demand increased (as the main source of demand), if temperatures rose (implying that heat encouraged drinking), or if summer rains increased (damaging crops). According to these results climate seems to have had significant impacts on agriculture. Although this impact was not necessarily prolonged, since adaptation strategies and agricultural improvements will have mitigated it, these results do corroborate those of other studies that have suggested similar interpretations (Jones 1964, 1965; Overton 1989, 1996; Michaelowa 2001; Waldinger 2014; Brunt 2004, 2015; Campbell 2010, 2016). 
The regression Models 3 and 4 present two stationary demographic variables (marriage and mortality) and climatic data are taken as explanatory variables. The minimumquadratic regressions show a significant (positive) relationship with average annual temperatures and spring rainfall in the case of marriages, explaining 50 percent of the endogenous variable. The result suggests that good weather (which meant good harvests) was a factor that influenced decisions to get married. According to the literature, during this period in England marriages were the key demographic indicators except in London, where there was a higher mortality and immigration (Beier and Finlay 1986).

The annual series of gross deaths shows a greater correlation with the increase in humidity (spring and summer rainfall), as well as winter and summer temperatures (colder winters and hotter summers being worse), together with an indicator of morbidity (deaths from sick people in the previous year). All other factors remaining constant, a one degree Celsius increase in summer temperature caused 12,868 additional deaths, and a similar fall in winter temperatures caused around 4,404 deaths. If spring and summer rainfall increased by $50 \mathrm{~mm}$, the number of deaths increased by 16,600 and 8,350 respectively. Thus, a year in which all of these changes occurred simultaneously meant an increase in the number of deaths by 42,222 people. Therefore, we again detect clear indications of the impact of climatic variables on population dynamics. These results are noteworthy and deserve further analysis beyond the scope of this article. 
Figure 1. Relative frequency of monthly minimum temperatures between the periods 1659-1700 and 19001940, England.

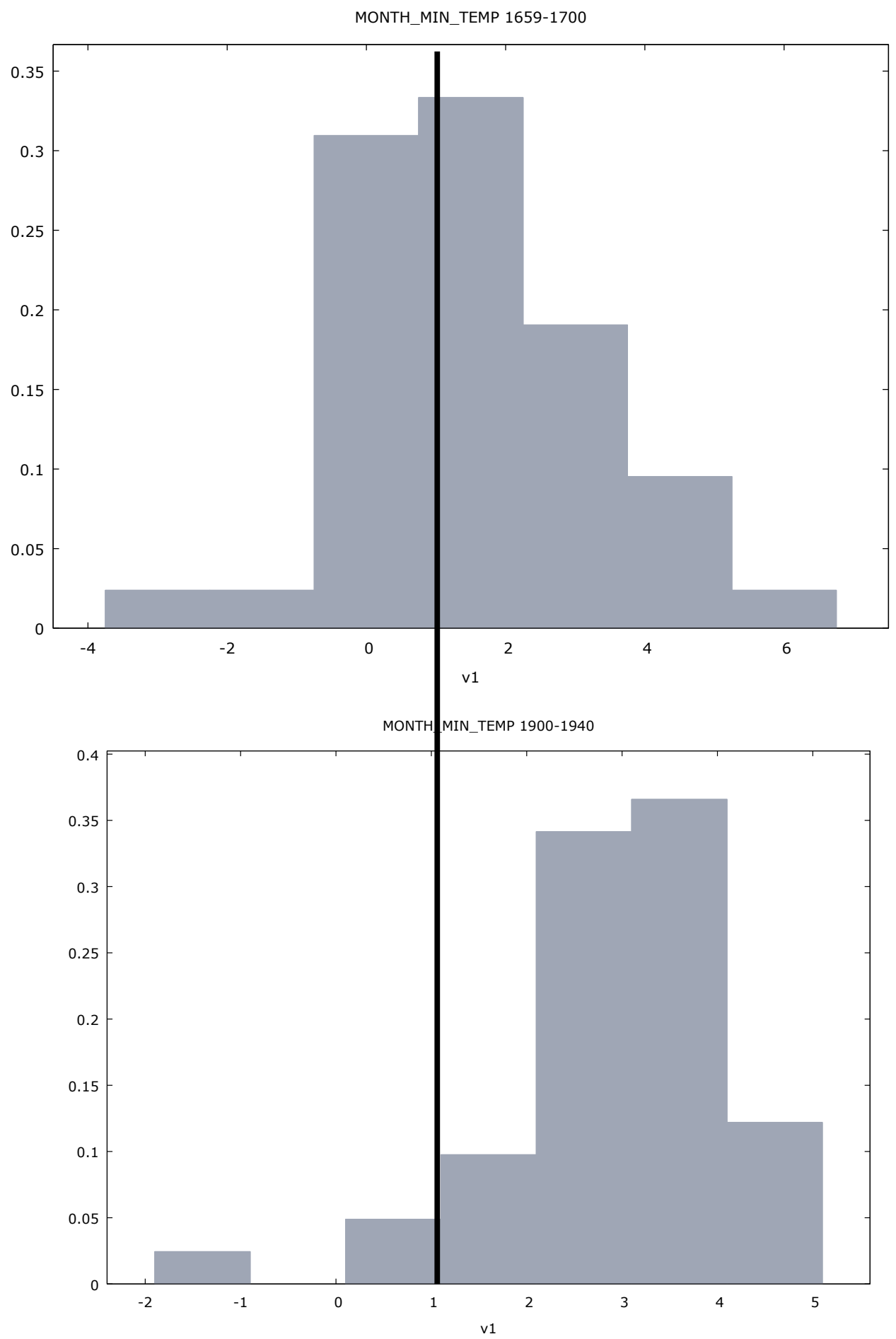

Own elaboration from English CET Temperatures. First, we calculate the distribution of the relative frequency of the monthly minimum temperatures in the periods 1900-1940 and 1659-1700. Then, we compared both distributions. We observe how in the $20^{\text {th }}$ century the minimum temperatures reached were much milder. The population did not have to endure so much cold, but it also had more resources. 
Table 2 (see supplementary material) measures the relationship between climate and energy consumption. In Model 1, 73 percent of the London coal price is explained by autumn and winter temperatures, and Newcastle coal shipments. The colder the temperature, more expensive the coal was, and vice versa. $\mathrm{A} 1^{\circ} \mathrm{C}$ reduction in temperature resulted in a price increase of 2.13 shillings, 15 percent in the average price of coal for the period studied. Knowing that the 1645-1700 period was especially cold, we understand that it was an important added stimulus to the demand of fuel per head. The lower the coal shipments, the more expensive it was. On the other hand, Hatcher (1993) has shown that shipments were radically reduced when the weather worsened, especially in autumn and winter. Therefore, the increase in prices reflects two things, an increase in the demand for heat, and an increase in the relative scarcity of coal. At that time, it was not easy to increase total winter energy consumption in proportion to low temperatures. According to this, total consumption could be more related to average temperatures based on forecasts and expectations.

Model 2 in Table 2 measures the relationship between the average fall in temperatures and an increase in coal consumption (total and per capita) between 1661 and 1700. A one degree Celsius fall in temperatures caused an average 35 percent increase in coal consumption. This result can be benchmarked knowing that in a developed country like the United States between 1988 and 1994 poor families increased their monthly fuel expenditure by 32 percent in winter, having to reduce their food intake measured in calories by 10 percent (Bhattacharya et al. 2003). However, if the explanatory capacity is 60 percent up to 1700 , it falls to 21 percent when the later warm period is included (Model 3). All of this suggests that the Maunder minimum accelerated the ongoing energy transition by increasing coal consumption during the fall in temperatures. According to Paolo Malanima, the energy divergence between England and Italy may have been accentuated during this period (Malanima 2015; Kander et al. 2013).

To expand Model 2, we added two proxy variables for urbanization/proto-industry, specifically, the ratio of craftsmen wages/agricultural wages (a higher wage gap in favour of non-agricultural wages indicates urbanization) and population (the higher the population, the greater the demand). These last two variables do not seem significant in the cold period, whereas temperatures do (Model 5). However, if we incorporate the later 
warm phase, it is the variables of urbanization and population and not temperatures that bear the main weight of the model (Model 4). All of this suggests a very logical conclusion: colder temperatures would accelerate the consumption of coal, contrary to what happened in the warmer period, when temperatures would lose importance in favour of other demand factors (urbanization and population). This interesting idea doubtless requires further research: the coal consumption series is weakly stationary, and the climatic ones are stationary. Likewise, the population series is first-order integrated and the ratio of craftsman-agricultural wages is weakly stationary. Although there does not appear to be a spurious relationship if we compare the adjusted determination coefficient and the DW statistic (Granger 1974), we cannot know whether the possible impacts detected are short or long-term in nature, and even whether they are small or large. Nor do we have more exogenous annual explanatory variables of minimum sufficient quality. A much broader analysis is here required.

\section{2 Economic impacts}

\subsubsection{Productivity and wages}

Table 3 (see supplementary material) presents the relationships between climate, physical labour productivity and wages. The results of Model 1 show climatic data to be associated with the average physical labour productivity (bushels/worker) by 58 percent. Lower winter temperatures and more intense summer rains have a negative impact on physical labour productivity, an effect that lasts for several years. Models 2 and 3 show the effects of climate on daily agricultural wages. First, the coefficients of determination indicate that these are not as sensitive to climatic variations as productivity, that is, changes in physical productivity do not translate into wage changes of the same order, implying that daily agricultural wages are not a good indicator of productivity. Second, despite the above, wages are more sensitive to cold weather ( 37 percent) than in the later warm period (19 percent). That is, when temperatures fell, so did daily agricultural wages, while in the warm period, when temperatures rose, the response was not the same, as if there were a ceiling difficult to overcome. 
Models 4 and 5 show the relationship between climatic variables and daily wages of craftsmen. The explanatory capacity of the climate in the long period is much greater for craftsmen's daily wages than for those of agricultural workers (51 percent versus 19 percent). This could be a sign of the former being a more flexible market. The great surprise is that, although a positive direct relationship is found with temperatures throughout the period, the relationship is the opposite during the cold period, with higher daily wages during colder periods, although the sensitivity is lower. As regards daily wages of construction workers (Models 6 and 7), the coefficient of determination during the cold period is 67 percent, and 43 percent for the entire period; that is, they were more sensitive during the cold period, and lower temperatures also pushed them upwards.

In summary, the most noteworthy facts here are, first, that there are indications of the impact of climate on physical labour productivity and daily wages, as expected according to the literature. We can also see that labour productivity accounted in energy terms moves in a similar way to temperatures, and the same happens with real daily wages, a trend verified in Figure 2. Second, daily agricultural wages were more rigid than nonagricultural wages, while this should not be the case in an economic activity that depends much more on natural factors: the result suggests institutional differences between sectors. Third, a colder climate seemed to be a stimulus for non-agricultural daily wages, a finding which is fully consistent with the review of the literature. However, extreme caution is required when drawing conclusions here. All the data used is too aggregated and entails reliability problems to venture definitive conclusions. All series except for craftsmen's daily wages are stationary, which prevents us from studying a long-term relationship, even if we can detect that the possible impacts of the climate lasted several years.

Once again, it could be claimed that these results have been obtained omitting a fundamental force such as population which, in theory, conditions movements in wages and living standards according to Malthusian reasoning. However, in Table 4 (see supplementary material) we observe that agricultural daily wages (within their great rigidity) show a little short-term sensitivity only to climate (17 percent), but not to population or the other demographic variables ( 0 percent). Something similar occurs with real daily agricultural wages, with the climate having an apparent global effect of 34 
percent whereas the effect of population is zero, and if we include other demographic variables their importance is similar, but no greater (Table 4). Furthermore, in the case of non-agricultural daily wages (craftsmen), their effects are similar, whether taken individually or jointly (61-60-68 percent). All of this indicates that we should not underestimate climate, and that the above conclusions are more than pure conjecture. As we saw in the previous section, there are reasons to think that population was also conditioned by changes in the climate.

\subsubsection{Aggregated economic growth}

Current studies on the relationships between climate change and modern economies have already detected different degrees of relationship (Stern 2007; Dell et al. 2014). Therefore, in an economy much more dependent on climate and nature, relationships between the two spheres should be more intense. The models presented above suggest that agricultural production contributed to the increase in total and per capita output during the Maunder Minimum, while energy consumption accelerated and daily wages rose, which leads us to think of an increase in GDP. To do this exercise, in Table 5 (see supplementary material) we analyse the relationship between the variables for the whole period 1661-1740. The coefficients of the main climatic variables are significant, with an $\mathrm{R}^{2}$ of 56 percent. Higher temperatures and spring rainfall resulted in a higher GDP, and the opposite was true when volcanic dust was present in the atmosphere or summer rains increased. One of the reasons for this impact on GDP is the increase in agricultural production, especially during the first part of the $18^{\text {th }}$ century, thanks to the innovations introduced by farmers to cope with the previous cold phase (Tello et al. 2017). Higher temperatures and benign spring rains facilitated the plants' $\mathrm{N}$ uptake and growth. On the other hand, excessive storms and summer rainfall endangered crops.

Following the impacts on the agrarian sector, a temperature increase by one degree Celsius, while keeping the rest of the variables constant, relates to a 4.73 percent rise in GDP. A $50 \mathrm{~mm}$ increase in spring rainfall led to a 6.78 percent rise in GDP (in the year 1700, GDP=100). Conversely, during the cold period the worsening of the climate correlated with an acceleration of growth, following the same trend as observed in energy consumption (food and coal), as well as in the daily wages of craftsmen and construction. 
The $1{ }^{\circ} \mathrm{C}$ drop in temperature relates to a GDP growth of 12.79 points. These results suggest that non-agricultural daily wages were a good qualitative indicator of the direction taken by GDP, and that some of the causes of the notable increase in GDP that occurred in the second half of the $17^{\text {th }}$ century were due to a combination of the agricultural improvements started to tackle the colder conditions, energy consumption and urban and proto-industrial development. Likewise, they would support the start of the English Agricultural Revolution as well as the theory of the Industrious Revolution proposed by De Vries (1994), both situated within the context of a worsening climate. In this sense, Allen and Weisdorf (2011) have suggested that it was the urban and craftsmen's families that were at the forefront of the modern consumer revolution (Broadberry et al. 2015).

Figure 2. Comparison of wheat-labour productivity: (a) and real agricultural daily wages (b) with temperatures, England, 1659-1740. Standardized data.

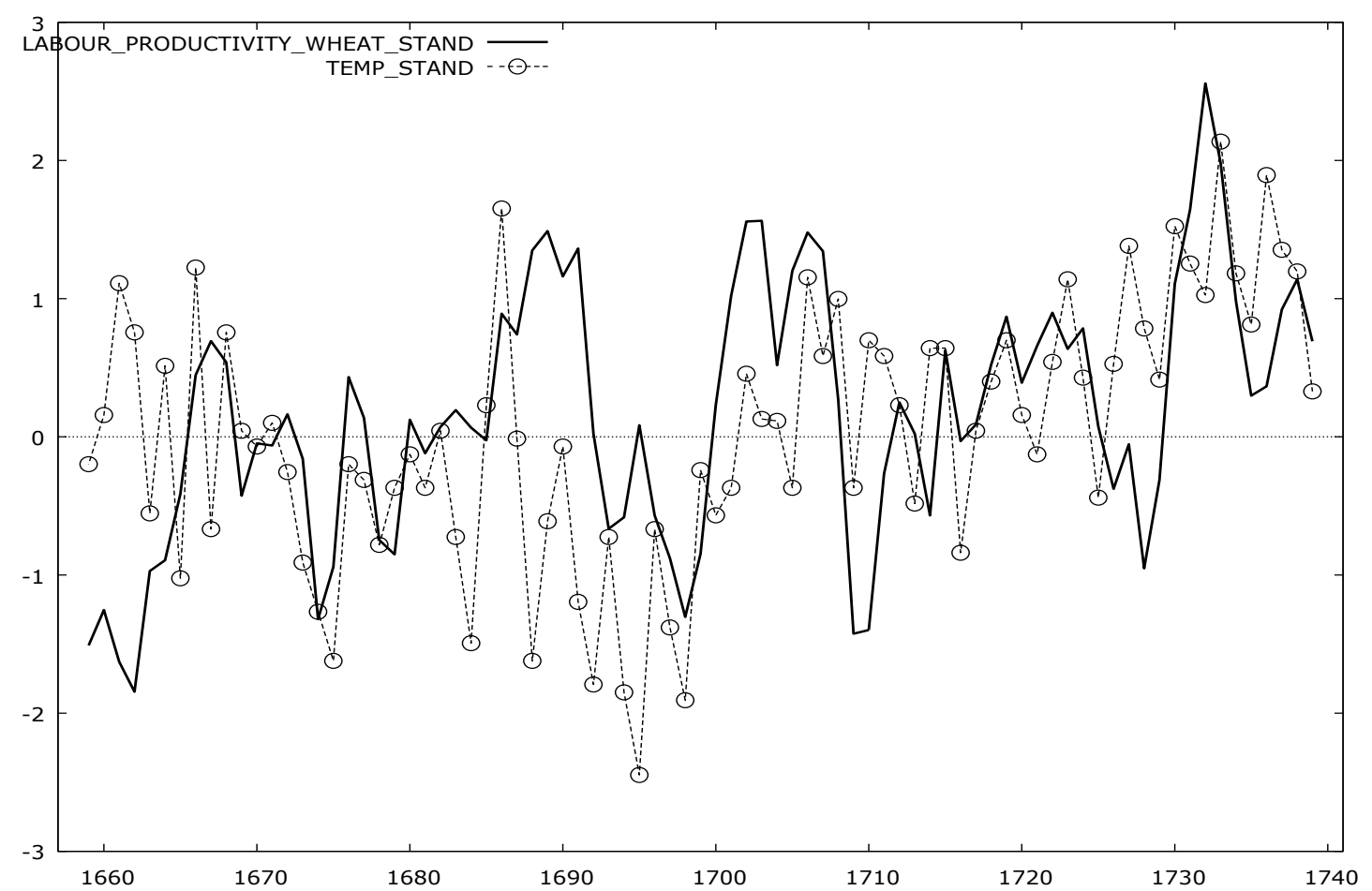




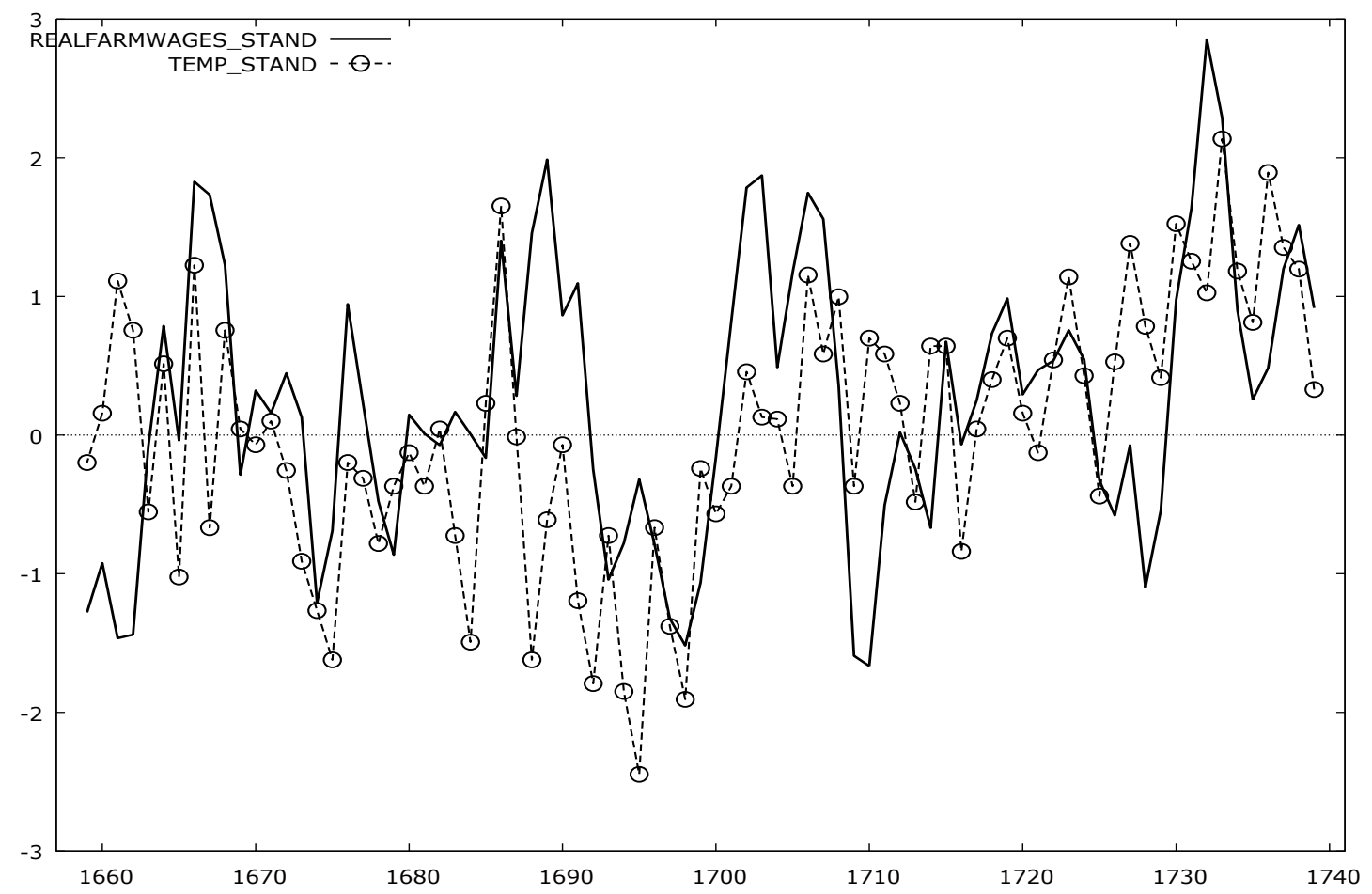

Source: TEMP_STAND, LABOUR_PRODUCTIVITY_WHEAT_STAND, and

REALFARMWAGES_STAND are standardized series based on their means and variances.

Temperatures, productivity and real wages move in a similar way. For more information, see section 3 ,

"Sources and Methodology".

\section{Conclusions}

The results obtained clearly indicate that climatic variation was a relevant factor in the transformations that occurred in England during the period 1645-1740. According to the best aggregated data available and using the standard econometric model for that purpose (Dell et al. 2014), a significant relationship between climate variables and wheat and barley production, population dynamics, energy consumption, productivity, wages and income (GDP) is confirmed.

A noteworthy result is that the short-term negative impact of colder temperatures on wheat production did not led to long-term intensification of climate impacts on English agriculture during the first phase of the Maunder Minimum, according to the available production series. This can only be explained by agricultural improvements and adaptations carried out as a response to climatic conditions as well as to the growing rural and urban per head energy demand for food, and government incentives. The increase of agricultural produce of wheat and barley intensified during the second phase of the 
Maunder Minimum at the beginning of the $18^{\text {th }}$ century, thanks to the ongoing dynamics of more favourable climate conditions, the keeping of the efforts to improve agricultural production, and growing urban and industrious demand (Tello et al. 2017).

The more adverse climate during the first phase of the Maunder Minimum also stimulated fuel energy consumption, and thus GDP. In the short term, we find climatic impacts (worsening) on the population (decreasing), mortality (increasing), marriages (decreasing). From here, we observe two forces. First, the climate and demographic deterioration led to a greater need for energy consumption per person to maintain basal metabolism, health and a level of energy enough to work and live. Second, rural and urban expansion required more energy per person to work. The convergence of the two forces may explain the result of our econometric models: a growth in energy demand and wages, and consequently, an increase in income and expenditure despite the climate worsening.

Given the need to be more productive and spend more in a colder, wetter and more unstable context, the rigidity detected in daily agricultural wages suggests a reallocation of labour through different means, whether outside or within the agrarian sector. Depending on the capacities of each family, each social class and each region, that combination of driving forces ended up being associated with an improvement in aggregate income, and therefore in real GDP, in a way that avoided England to be caught in a Malthusian trap. When climate conditions improved in the second phase of the Maunder Minimum, the country had discovered a new economic path the continental Europe and the rest of the World would take it difficult to find.

Acknowledgements This collaborative research has been funded by the Spanish projects RTI2018-093970-B-C33, PGC2018-096350-B-100, and ECO2016-75805-R. We thank the anonymous reviewers and editors of this journal, as well as all the participants in the $\mathrm{PhD}$ Seminar in Economic History held at the University of Barcelona, for their valuable contributions that helped improve this article. 


\section{References}

Alfani G, Murphy TE (2017) Plague and Lethal Epidemics in the Pre-Industrial World. The Journal of Economic History 77 (1).

Allen RC (2009) The British Industrial Revolution in Global Perspective. Cambridge. Cambridge University Press.

Allen RC, Weisdorf JL (2011) Was there an 'industrious revolution' before the industrial revolution? An empirical exercise for England, c. 1300-1830. The Economic History Review 64 (3):715-729.

Almond D, Currie J (2011) Killing me softly: The fetal origins hypothesis. Journal of Economic Perspectives 25:153-172.

Appleby AB (1979) Grain Prices and Subsistence Crises in England and France, 1590-1740. Journal of Economic History 39 (4):865-887.

Appleby AB (1980) Epidemics and Famine in the Little Ice Age. The Journal of Interdisciplinary History 10 (4):643-663.

Beier A, Finlay R (eds) London 1500-1700: The Making of the Metropolis (1986). New York, Longman.

Bhattacharya J, Deleire T, Haider S, Currie J (2003) Heat or Eat? Cold-Weather Shocks and Nutrition in Poor American Families. American Journal of Public Health 93 (7).

Braga AL, Zanobetti A, Schwartz J (2001) The Time Course of Weather-related deaths. Epidemiology 12(6):662-667.

Braga AL, Zanobetti A, Schwartz J (2002) The Effect of Weather on Respiratory and Cardiovascular Deaths in 12 U.S. Cities. Environ Health Perspect. 110(9):859-863.

Brázdil R, Drobrovolný, Luterbacher J, Moberg A, Pfister CH, Wheeler D, Zurita E (2010) European climate of the past 500 years: new challenges for historical climatology. Climatic Change 101:7-40.

Broadberry S, Campbell B, Klein A, Overton M, Bas van Leeuwen (2015) British Economic Growth, 1270-1870. Cambridge University Press.

Brunt L (2004) Nature or Nurture? Explaining English Wheat Yields in the Industrial Revolution, c.1770. The Journal of Economic History 64 (1):193-225.

Brunt L (2015) Weather Shocks and English Wheat Yields, 1690-1871. Explorations in Economic History 57:50-58- https://doi.org/10.1016/j.eeh.2014.12.001

Camenisch et al. (2016) The 1430s: a cold period of extraordinary internal climate variability during the early Spörer Minimum with social and economic impacts in north-western and central Europe. Climate of the Past 12:2107-2126. www.clim-past.net/12/2107/2016/doi:10.5194/cp-12-2107-2016.

Camenisch C, Rohr C (2018) When the Weather Turned Bad. The Research of Climate Impacts on Society and Economy during the Little Ice Age in Europe. An Overview. Cuadernos de investigación geográfica 44(1):99-114. Universidad de La Rioja. http://doi.org/10.18172/cig.3395

Campbell BMS (2010) Nature as historical protagonist: environment and society in pre-industrial England. Economic of History Review 63 (2):281-314.

Campbell BMS (2016) The Great Transition: Climate, Disease and Society in the Late-Medieval World. Cambridge University Press.

Claessens van Ooijen AM, Westerterp KR, Wouters L, Schoffelen PF, Steenhoven AA, Lichtenbelt WD (2006) Heat Production and Body Temperature During Cooling and Rewarming in Overweight and Lean Men. Obesity 14:1914-1920. https://doi.org/10.1038/oby.2006.223 
Clark G (2002) The Agricultural Revolution and the Industrial Revolution: England, 1500-1912. Working Paper. http://www.econ.ucdavis.edu/faculty/gclark/research.html

Clark G (2004) The Price History of English Agriculture, 1209-1914. Research in Economic History 22: 41-124.

Clark G (2005) The Condition of the Working-Class in England, 1209-2004. Journal of Political Economy (113) 6:1307-1340.

Clark G (2007) The Long March of History: Farm Wages, Population and Economic Growth, England 1209-1869. Economic History Review 60 (1):97-135.

Coleman DC (1956) Labour in the English Economy of the Seventeenth Century. The Economic History Review (8) 3:280-295.

Collins, M.; Osborn, T. J.; Tett, S.F. B.; Briffa, K. R.; F. H. Schweingruber (2002): A Comparison of the Variability of a Climate Model with Paleotemperature Estimates from a Network of Tree-Ring Densities, Jorunal of Climate, vol 15, n 13, pp. 1497-1515.

Cooper RJ, Melvin I, Tyers RJS, Wilson K, Briffa (2012) A Tree-ring Reconstruction of East Anglian (UK) Hydroclimate Variability over the Last Millennium. Clim Dyn.

Cullen K (2010) Famine in Scotland-the 'Ill Years' of the 1690s. Vol. 16. Edinburgh University Press.

Crafts N, Mills TC (2017) Six centuries of British economic growth: a time-series perspective. European Review of Economic History 21:141-158.

Dell M, Jones BF, Olken BA (2012) Temperature Shocks and Economic Growth: Evidence from the Last Half Century. American Economic Journal: Macroeconomics 4 (3):66-95.

Dell M, Jones BJ, Olken BA (2014) What Do We Learn from the Weather? The New Climate-Economy Literature. Journal of Economic Literature 52(3):740-798. https://dx.doi.org/10.1257/jel.52.3.740

Deschênes O, Greenstone M (2012) The economic impacts of climate change: evidence from agricultural output and random fluctuations in weather: reply. The American Economic Review 102 (7):3761-3773.

Eddy J (1976) The Maunder Minimum. Science, 192 (4245):1189-1202.

Feola G, Lerner A, Jain M, Montefrio M, Nicholas K (2014) Farmer responses to multiple stresses in the face of global change: Assessing five case studies to enhance adaptation. http://ifsa.boku.ac.at/cms/fileadmin/Proceeding2014/WS 33 Feola.pdf

Finzi R (1986) Il sole, la pioggia, il pane e il lavoro. Note su clima, raccolto, calendario agrario nel Bolognese durante il secolo XVIII In: Finzi R (ed) Le Meteore e il Frumento: clima, agricoltura, meteorologia a Bologna nel, 1700, Bologna, Il Mulino, pp 347-387.

Finzi R (1998) La necessità di lavoro salariato svelata dalla storia climatica Civiltà mezzadrile. In Finzi $\mathrm{R}$ (ed) La picole coltura in Emilia-Romagna, Roma-Bar, Editori Laterza, pp 34-65.

Flinn MW (1985) History of the British coal industry, 2: 1700-1830: The industrial revolution. Oxford.

Galloway P (1985) Annual variations in deaths by age, deaths by causes, prices and weather in London, 1670 to 1830. Population Studies XXXIX:487-505.

Galloway P (1986) Long-Term Fluctuations in Climate and Population in the Pre-Industrial Era. Population and Development Review 12 (1):1-24.

Galloway P (1994) Secular Changes in the Short-Term Preventive, Positive and Temperature Checks to Population Growth in Europe, 1460 to 1909. Climate Change 26 (1): 3-63. 
Graff Zivin J, Neidell MJ (2014) Temperature and the Allocation of Time: Implications for Climate Change. Journal of Labor Economics 32:1-26.

Graff Zivin J, Shrader MJ (2015) Environment, Health, and Human Capital. Journal of Economic Literature 51 (3):689-730.

Graff Zivin J, Neidell J (2016) Temperature extremes, health, and human capital. Future of Children $26: 31-50$

Granger CW, Newbold P (1974) Spurious Regression in Econometrics. Journal of Econometrics, 2 (2):111-120.

Hatcher, J (1993) The History of the British Coal Industry. Volume I: Before 1700: Towards the Age of Coal. New York: The Clarendon Press, Oxford University Press.

Hatcher J (2003) The emergence of a mineral-based energy economy in England, c. 1550-c.1850. In Cavaciocchi S (ed) Economia e energia, pp 483-504.

Heal G, Park J (2016) Temperature Stress and the Direct Impact of Climate Change: A Review of an Emerging Literature. Review of Environmental Economics and Policy 10 (2):347-362.

Holopainen J, Helama S. Hum Ecol (2009) Little Ice Age Farming in Finland: Preindustrial Agriculture on the Edge of the Grim Reaper's Scythe 37(2): 213. https://doi.org/10.1007/s10745-009-9225-6

Houston RA (1996) The Population History of Britain and Ireland, 1500-1750. In Anderson M (ed) British population history: from the Black Death to the present day, Cambridge University Press, pp 95-191.

Hoyle RW (2013): Why was there no Crisis in England in the 1690's?. In Hoyle RW (ed) The Farmer in England, 1650-1980. Ashgate, Farnham, Centre for Economic History University of Reading, pp 69100.

Hoyle RW (2018) A harvest gathered in: some implications of British economic growth, 1270-1870 for agricultural history. The Agricultural History Review 66 (1):112-131.

Jones EL (1964) Seasons and Prices: the role of the Weather in English Agricultural History. Allen \& Unwin, London.

Jones EL (1965) Agriculture and Economic Growth in England, 1660-1750: Agricultural Change. In Jones, EL (ed) Agriculture and Economic Growth in England, 1660-1750. A University Paperback Original, pp 152-171.

Kander A, Malanima P, Warde P (2013) Power to the People. Energy in Europe over the Last Five Centuries. Princeton and Oxford: Princeton University Press.

Keatinge WR, Donaldson GC, Cordioli E, Martinelli M, Kunst AE, Mackenbach JP, Nayha S, Vuori I (2000) Heat related mortality in warm and cold regions of Europe: observational study. BMJ, 321:670-673.

Kelly M, Ó Gráda C (2014) Change Points and Temporal Dependence in Reconstructions of Annual Temperature: did Europe experience a Little Ice Age?. The Annals of Applied Statistics 8 (3):13721394.

Koch A, Brierley C, Maslin MM, Lewis SL (2018). Earth system impacts of the European arrival an d Great Dying in the Americas after 1492. Quaternary Science Reviews 207:13-36.

Koepke N, Baten J (2005) Climate and its impact on the Biological Standard of living in northeast, Centre-west and South Europe during the last 2000 years. History of Meteorology. 
Kussmaul A (1981) Servants in Husbandry in Early Modern England. Cambridge. Cambridge University Press.

Luterbacher J, Rickli R, Xoplaki E, Tinguely C, Beck C, Pfister C, Wanner H (2001) The Late Maunder Minimum (1675-1715). A Key Period for Studying Decadal Scale Climatic Change in Europe. Climatic Change 49(4):441-462.

Mäkinen TM (2006) Human cold exposure, adaptation and performance in a northern climate. Faculty of Medicine, Department of Physiology, Centre for Arctic Medicine, Thule Institute, University of Oulu, Finland. http://jultika.oulu.fi/files/isbn951428089X.pdf, Accessed 12.07.2018.

Malanima P (2015) Energy consumption in England and Italy, 1560-1913. Two pathways towards energy transition. Economic History Review 69:78-103. https://doi.org/10.1111/ehr.12109

Manley G (1974) Monthly Mean Central England Temperature, 1659-1973. Q.J.R.Meteorol.Soc. 100:389-405.

Mann ME, Gille EP, Bradley RS, Hughes MK, Overpeck JT, Keimig FT, Gross WS (2000) Global Temperature Patterns in Past Centuries: An Interactive Presentation. Earth Interactions 4 (4). IGBP Pages/World Data Center for Paleoclimatology. Data Contribution Series \#2000-075. NOAA/NGDC Paleoclimatology Program, Boulder CO, USA.

Martens WJM (1998) Climate Change, Thermal Stress and Mortality Changes. Soc. Sci. Med.46(3):331344.

Martínez González JL (2016) Construyendo una serie física anual de trigo en Inglaterra (1645-1761). Metodología, retos y oportunidades. Primera evaluación práctica mediante la relación semillas locales-revolución agrícola. Working Paper, AEHE. http://econpapers.repec.org/paper/ahedtaehe/

Martínez González JL, Jover Avellà G, Tello E (2019) Building an English Wheat Annual series in an intriguing era (1645-1761): Methodology, challenges and opportunities. Revista de Historia Agraria, 79 (december).

Michaelowa A (2001) The Impact of Short-Term Climate Change on British and French Agriculture and Population in the First Half of the $18^{\text {th }}$ Century. In Jones P, Olgivie A, Davis T (eds): History and Climate. Memories of the Future. Kluver, New York, pp 201-218.

Ocobock, C. (2014). Measuring and Predicting Total Energy Expenditure Among Highly Active Humans in Natural Environments. All Theses and Dissertations (ETDs). https://doi.org/https://doi.org/10.7936/K7MW2F4Q.

Ocobock, C. (2016). Human energy expenditure, allocation, and interactions in natural temperate, hot, and cold environments. American Journal of Physical Anthropology. https://doi.org/10.1002/ajpa.23071

Ormrod D (1985) English Grain Exports and the Structure of Agrarian Capitalism, 1700-1760. Hull.

Overton M (1989) The Determinants of Crop Yields in Early Modern England. In Campbell B, Overton M (eds) Land, Labour and Livestock: Historical Studies in European Agricultural Productivity. Manchester University Press, Manchester.

Overton M (1996) Agricultural Revolution in England: The Transformation of the Agrarian Economy, 1500-1850. Vol. 178. Cambridge: Cambridge University Press.

Owens MJ, Lockwood M, Hawkins E, Usoskin I, Jones GS, Barnard L, Schurer A, Fasullo J (2017) The Maunder minimum and the Little Ice Age: an update from recent reconstructions and climate simulations. J. Space Weather Space Clim. 7, A33, Published by EDP Sciences 2017. https://doi.org/10.1051/swsc/2017034 (Access 13 Jan 2018). 
Park J, Heal G (2013) Feeling the Heat: Temperature, Physiology \& the Wealth of Nations. Working Paper 19725. Cambridge, MA: NBER.

Parker G (2013) Global Crisis. War, Climate Change and Catastrophe in the Seventeenth Century. Yale University Press, New Haven and London.

Parry ML (1978) Climatic Change, Agriculture and Settlement, Folkeston, Dawson, Archon Books.

Parsons, K. (2014) Human thermal environment. The effects of hot, moderate and cold temperatures on human health, 3rd edn. CRC Press, New York.

Pei Q, Zhang DD, Lee HF, Li G (2016) Crop Management as an Agricultural Adaptation to Climate Change in Early Modern Era: A Comparative Study of Eastern and Western Europe. Agriculture 6 (3) 29. https://doi.org/10.3390/agriculture6030029

Pillay C, Van den Bergh J (2016) Human health impacts of climate change as a catalyst for public engagement: Combining medical, economic and behavioural insights. International Journal of Climate Change Strategies and Management 8 (5):578-596. http://dx.doi.org/10.1108/IJCCSM-06-2015-0084.

Powell JP, Reinhard S (2016) Measuring the Effects of Extreme Weather Events on Yields. Weather and Climate Extremes 12:69-79. http://dx.doi.org/10.1016/j.wace.2016.02.003

Rinne KT, Loader NJ, Switsur VR, Waterhouse JS (2013) 400-Year-August Precipitation Reconstruction for Southern England using Oxygen Isotopes in Tree Rings. Quaternary Science Reviews 60:13-25.

Seppänen O, Fisk WJ, Lei QH (2006) Effect of temperature on task performance in office environment. Lawrence Berkeley National Laboratory, LNBL report 60946.

Sydenham T (1676) Observationes medicae circa morborum acutorum historiam et curationem. Londoni, G. Kettilby.

Smil V (2017) Energy and Civilization: A History. Cambridge, MA: MIT Press.

Stenseth NC, Samia NI, Viljugrein H (2006) Plague dynamics are driven by climate variation. PNAS 103(35):13110-13115.

Stern N (2007) The Economics of Climate Change. The Sterpowelln Review. Cambridge University Press.

Tello E, Martínez-González JL, Jover G, Olarieta JR, García-Ruiz R, González de Molina M, Badia-Miró M, Winiwarter V, Koepke N (2017) The Onset of the English Agricultural Revolution: Climate Factors and Soil Nutrients. The Journal of Interdisciplinary History 47 (4):445-474.

Vries J de (1984) European urbanization: 1500-1800. London: Methuen, 1984.

Vries J de (1994) The Industrial Revolution and the Industrious Revolution. Journal of Economic History 54:249-70.

Waldinger M (2014) The Long-Term Effects of Climatic Change on Economic Growth: Evidence from the Little Ice Age, 1500 - 1750. Working Paper. London School of Economics.

Warde, P (2007) Energy consumption in England \& Wales, 1560-2000. Consiglio Nazionale delle Ricerche. Istituto di Studi sulle Società del Mediterraneo.

Wilson R, Miles D, Loader NJ, Melvin T, Cunningham L, Cooper R, Briffa K (2012) A millennial long March-July precipitation reconstruction for southern-central England. Climate Dynamics.

White S (2014) The Real Little Ice Age. Journal of Interdisciplinary History 44 (3). 
Wrigley EA (1985) Urban Growth and Agricultural Change: England and the Continent in the Early Modern Period. The Journal of Interdisciplinary History 15 (4):683-728.

Wrigley EA (2010) Energy and the English Industrial Revolution. Cambridge; New York: Cambridge University Press.

Wrigley EA, Schofield RS (1981) The Population History of England, 1541-1871: A Reconstruction.

London: Revised paperback edition, 1989.

\title{
Supplementary material
}

\section{ASSESSING CLIMATE IMPACTS ON ENGLISH ECONOMIC GROWTH (1645- 1740): AN ECONOMETRIC APPROACH}

\author{
José Luis Martínez González ${ }^{2}$ \\ Jordi Suriñach ${ }^{3}$ \\ Gabriel Jover ${ }^{3}$ \\ Javier Martín-Vide ${ }^{4}$ \\ Mariano Barriendos Vallvé 5 \\ Enric Tello 6
}

\section{Introduction}

This supporting information provides detailed information from Tables 1, 2, 3, 4, 5 .

\footnotetext{
${ }^{2}$ Researcher at the Department of Economic History and Institutions, Faculty of Economics and Business, 690 Diagonal Avenue, 08034 Barcelona.

${ }^{3}$ Full professor of Applied Economics at the University of Barcelona, AQR Research Group. Faculty of Economics and Business, 690 Diagonal Avenue, 08034 Barcelona.

${ }^{3}$ Gabriel Jover-Avellà is Senior Lecturer of History, University of Girona. Campus Montilivi, 17003 Girona.

${ }^{4}$ Full professor of Physical Geography, Director of the Climatology Group, Department of Geography, University of Barcelona.

${ }^{5}$ Department of History and Archaeology, University of Barcelona.

6 Professor of Environmental and Economic History, University of Barcelona. Department of Economic History, Institutions, Policy and World Economy, Faculty of Economics and Business.
} 
Table 1. Response of gross wheat production, marriages and deaths, to temperatures, rainfall, craftsmen's daily wages and the Corn Bounties paid in exports, $1645-1740$.

\begin{tabular}{|c|c|c|c|c|}
\hline Dependent variable and methods & $\begin{array}{l}\text { Gross Wheat Production } \\
\text { in bushels, OLS (1) }\end{array}$ & $\begin{array}{l}\text { Barley Price } \\
\text { OLS (2) }\end{array}$ & $\begin{array}{l}\text { Marriages } \\
\text { OLS (3) }\end{array}$ & $\begin{array}{l}\text { Deaths } \\
\text { OLS (4) }\end{array}$ \\
\hline $\begin{array}{l}\text { Constant } \\
\text { TEMPERATURE } \\
\text { TEMPERATURE (-1) } \\
\text { TEMPERATURE (-2) } \\
\text { SUMMER TEMPERATURE (-1) } \\
\text { WINTER TEMPERATURE (-2) } \\
\text { SUMMER RAINFALL } \\
\text { SUMMER RAINFALL (-1) } \\
\text { SPRING RAINFALL } \\
\text { SPRING RAINFALL (-1) } \\
\text { SPRING RAINFALL (-2) } \\
\text { SUMMER RAINFALL (EAST) } \\
\text { DEATHS_YEAR (-1) } \\
\text { GROSS WHEAT PRODUCTION } \\
\text { BEER_PRICE (-1) } \\
\text { BARLEY PRICE (-1) } \\
\text { CRAFT WAGES (-2) } \\
\text { CORN BOUNTIFS }\end{array}$ & $\begin{array}{l}25.2808 * * * * \\
(<0.001) \\
0.959425 * * \\
(0.0129) \\
\\
\\
0.844384 * * \\
(0.0377) \\
\\
\\
\\
-0.0137884 * * * \\
(<0.001) \\
-0.0191260 * * * \\
(<0.001)\end{array}$ & $\begin{array}{l}-0.00063621^{*} \\
(0.0767)\end{array}$ & $\begin{array}{l}36.2327 * * \\
(0.0169) \\
46.6197 * * * \\
(<0.001) \\
\\
-39.4568^{*} \\
(0.0609)\end{array}$ & $\begin{array}{l}7464.47 * * * \\
(0.0021) \\
-2554.86 * * \\
(0.0483) \\
\\
96.9867 * * * \\
(0.0006)\end{array}$ \\
\hline $\begin{array}{l}\mathrm{N} \\
R^{2} \\
F\end{array}$ & $\begin{array}{l}80 \\
0.46 \\
16.24 \\
\end{array}$ & $\begin{array}{l}80 \\
0.72 \\
35.26 \\
\end{array}$ & $\begin{array}{l}81 \\
0.50 \\
14.52 \\
\end{array}$ & $\begin{array}{l}79 \\
0.55 \\
17.56 \\
\end{array}$ \\
\hline
\end{tabular}

$*=$ level of significance at $10 \%, * *=$ level of significance at $5 \%, * * *=$ level of significance at $1 \%$, p-values in brackets. All series are stationary except wages (correlogram and ADF test). The linear functional form is accepted except in DEATHS (Test Reset). All series are homocedastic (White and Breusch-Pagan Tests) and free of multicollinearity (VIF). There are no problems of non-normality in the residuals, except in equation (4). In general, the fact that all of the series are stationary and do not violate the basic hypothesis of the multiple regression model makes the results robust. 
Table 2. Contrast in the response of London coal price and the consumption of coal to changes in temperatures, the correlation between craftsmen's wages/agricultural workers' wages, and population, England, 1659-1740.

\begin{tabular}{|c|c|c|c|c|c|}
\hline $\begin{array}{l}\text { Dependent variable } \\
\text { Length }\end{array}$ & $\begin{array}{c}\text { PR_COAL_LOND } \\
1661-1700 \\
(1)\end{array}$ & $\begin{array}{c}\text { COAL_EXPENSE } \\
1661-1700 \\
(2)\end{array}$ & $\begin{array}{c}\text { COAL_EXPENSE } \\
1661-1740 \\
(3)\end{array}$ & $\begin{array}{c}\text { COAL_EXPENSE } \\
1659-1740 \\
(4)\end{array}$ & $\begin{array}{c}\text { COAL_EXPENSE } \\
1661-1700 \\
(5)\end{array}$ \\
\hline Constant & $\begin{array}{c}47.4083^{* * * *} \\
(<0.001)\end{array}$ & $\begin{array}{c}7.54847 \mathrm{e}+08^{* * * *} \\
(<0.001)\end{array}$ & $\begin{array}{c}-2.67069 \mathrm{e}+08^{* *} \\
(0.0149)\end{array}$ & $\begin{array}{c}-1.30104 \mathrm{e}+09^{* * *} \\
(<0.001)\end{array}$ & $\begin{array}{c}9.16422 \mathrm{e}+08^{* * *} \\
(0.0113)\end{array}$ \\
\hline TEMPERATURE & & $\begin{array}{c}-2.64441 \mathrm{e}+07 * * * \\
(<0.001)\end{array}$ & & & $\begin{array}{c}-2.06657 \mathrm{e}+07 * * * \\
(<0.001)\end{array}$ \\
\hline TEMPERATURE (-1) & & $\begin{array}{c}-1.66796 \mathrm{e}+07 * * \\
(0.0284)\end{array}$ & $\begin{array}{c}2.79423 \mathrm{e}+07 * * \\
(0.0252)\end{array}$ & & $\begin{array}{c}-1.62709 \mathrm{e}+07^{* *} \\
(0.0262)\end{array}$ \\
\hline TEMPERATURE (-2) & & $\begin{array}{c}-2.57671 \mathrm{e}+07 * * * \\
(<0.001)\end{array}$ & $\begin{array}{c}2.59915 \mathrm{e}+07 * * \\
(0.0370)\end{array}$ & & $\begin{array}{c}-1.94363 \mathrm{e}+07 * * \\
(0.0124)\end{array}$ \\
\hline WINTER_TEMPERAT & $\begin{array}{c}-0.400246^{*} \\
(0.0517)\end{array}$ & & & & \\
\hline WINTER_TEMPERAT (-1) & $\begin{array}{c}-0.454780^{* *} \\
(0.0281)\end{array}$ & & & & \\
\hline AUTUMN_TEMPERAT & $\begin{array}{c}-1.28203 * * * \\
(<0.001)\end{array}$ & & & & \\
\hline COAL_SHIPPED & $\begin{array}{c}-2.4983^{* * * *} \\
(<0.001)\end{array}$ & & & & \\
\hline COAL_SHIPPED (-1) & $\begin{array}{c}-1.4555 * * * \\
(0.0016)\end{array}$ & & & & \\
\hline CRAFT_VERSUS_FARM & & & & $\begin{array}{c}1.79272 \mathrm{e}+08^{* * *} \\
\quad(<0.0001)\end{array}$ & $\begin{array}{c}5.82808 \mathrm{e}+07 \\
(0.1232)\end{array}$ \\
\hline POPULATION & & & & $\begin{array}{c}228.871 * * * \\
(<0.0001)\end{array}$ & $\begin{array}{c}-75.1825 \\
(0.2261)\end{array}$ \\
\hline$N$ & 40 & 40 & 80 & 82 & 40 \\
\hline$R^{2}$ & 0.72 & 0.60 & 0.21 & 0.66 & 0.66 \\
\hline$F$ & 21.26 & 17.82 & 10.28 & 77.55 & 13.12 \\
\hline
\end{tabular}

$*=$ level of significance at $10 \%, * *=$ level of significance at $5 \%, * * *=$ level of significance at 1\%,p-values in brackets. All series are stationary except POPULATION (correlogram and ADF test). COAL_EXPENSE and CRAFT_VERSUS_FARM are weakly stationary (the ADF test with constant and trend shows stationarity but not only with constant or observing the correlogram). The linear form of the function is accepted less in Model 3 (Test Reset). All series are homocedastic (Breusch-Pagan Tests) and free of multicollinearity (VIF). There are no problems of normality in the error, except in Models 1, 3 and 4. In general, the results are robust because almost all series are stationary and the basic hypotheses of multiple regression are not unmet. 
Table 3. Response of labour productivity, daily agricultural, craftsmen and construction wages, to changes in temperatures and rainfall, England, $1660-1740$.

\begin{tabular}{|c|c|c|c|c|c|c|c|}
\hline $\begin{array}{l}\text { Dependent variable } \\
\text { Length }\end{array}$ & $\begin{array}{c}\text { LABOUR_WHEAT } \\
\text { _PRODUCTIVITY } \\
1662-1740(\mathrm{~T}=79) \\
\text { (1) }\end{array}$ & $\begin{array}{c}\text { WAGE_FARM } \\
1661-1740 \\
(\mathrm{~N}=80) \\
(2)\end{array}$ & $\begin{array}{c}\text { WAGE_FARM } \\
1661-1700 \\
(\mathrm{~N}=40) \\
(3)\end{array}$ & $\begin{array}{c}\text { WAGE_CRAFT } \\
1661-1740 \\
(\mathrm{~N}=80) \\
(4)\end{array}$ & $\begin{array}{c}\text { WAGE_CRAFT } \\
1660-1700 \\
(\mathrm{~N}=41) \\
(5)\end{array}$ & $\begin{array}{c}\text { WAGE_BLDG } \\
1661-1740 \\
(\mathrm{~N}=80) \\
(6)\end{array}$ & $\begin{array}{c}\text { WAGE_BLDG } \\
1661-1700 \\
(\mathrm{~N}=40) \\
(7)\end{array}$ \\
\hline Constant & $\begin{array}{c}71.3199 * * * \\
(<0.0001)\end{array}$ & $\begin{array}{l}5.39511 * * * \\
(<0.001)\end{array}$ & $\begin{array}{c}-0.385809^{* * *} \\
(0.8706)\end{array}$ & $\begin{array}{l}13.5808^{* * *} \\
(9.21 \mathrm{e}-011)\end{array}$ & $\begin{array}{l}22.5172 * * * \\
(<0.001)\end{array}$ & $\begin{array}{c}14.6808 * * * \\
(<0.001)\end{array}$ & $\begin{array}{c}20.1029 * * * \\
(<0.001)\end{array}$ \\
\hline TEMPERATURE & & $\begin{array}{l}0.278425^{* * *} * \\
(0.0088)\end{array}$ & $\begin{array}{c}0.480456^{* *} \\
(0.0116)\end{array}$ & $\begin{array}{l}0.396996 * * * \\
(0.0052)\end{array}$ & (10.00 & & $\begin{array}{l}-0.203513 * * * \\
(0.0095)\end{array}$ \\
\hline & & & & & $\begin{array}{c}-0.359314 * * * \\
(0.0062)\end{array}$ & & $\begin{array}{l}-0.145596^{*} \\
(0.0624)\end{array}$ \\
\hline TEMPERATURE (-2) & & $\begin{array}{l}0.239523 * * \\
(0.0327)\end{array}$ & $\begin{array}{l}0.51029 * * * \\
(0.0082)\end{array}$ & $\begin{array}{l}0.402089 * * * \\
(0.0098)\end{array}$ & & $\begin{array}{l}-0.16471^{* *} \\
(0.0114)\end{array}$ & $\begin{array}{l}-0.3542 * * * \\
(<0.001)\end{array}$ \\
\hline WINTER_TEMPERAT & $\begin{array}{l}0.834778^{* * * *} \\
\quad(0.0021)\end{array}$ & & & & & & \\
\hline WINTER_TEMPERAT (-2) & $\begin{array}{c}0.690311^{* *} \\
(0.0167)\end{array}$ & & & & & & \\
\hline SPRING_TEMPERAT (-2) & $\begin{array}{c}-1.252 * * * \\
(0.0097)\end{array}$ & & & & & & \\
\hline AUTUMN_TEMPERAT (-2) & $\begin{array}{c}1.13671^{* * * *} \\
(0.0081)\end{array}$ & & & & & & \\
\hline SUMMER RAINFALL & $\begin{array}{c}-0.024 * * * \\
(<0.0001)\end{array}$ & & & & & & \\
\hline SUMMER RAINFALL (-1) & $\begin{array}{c}-0.0331451^{* * *} \\
(<0.0001)\end{array}$ & & $\begin{array}{c}0.00354286^{* * *} \\
(0.0445)\end{array}$ & & & $\begin{array}{c}-0.00123279 * * \\
(0.0364)\end{array}$ & $\begin{array}{c}-0.00251534^{* * * *} \\
(0.0009)\end{array}$ \\
\hline SUMMER RAINFALL (-2) & $\begin{array}{c}-0.0100019^{* *} \\
(0.0439)\end{array}$ & & $\begin{array}{c}0.00432863 * * \\
(0.0140)\end{array}$ & & & $\begin{array}{c}-0.00112526^{*} \\
(0.0504)\end{array}$ & $\begin{array}{c}-0.00160487^{* *} \\
(0.0212)\end{array}$ \\
\hline $\begin{array}{l}\text { SUMMER RAINFALL } \\
\text { (EAST) }\end{array}$ & & & & $\begin{array}{c}-0.0127439^{* * *} \\
(0.0013)\end{array}$ & & $\begin{array}{c}-0.00674929^{* * * *} \\
(<0.001)\end{array}$ & \\
\hline $\begin{array}{l}\text { SUMMER } \\
\text { (EAST) }(-1)\end{array}$ & & & & & $\begin{array}{c}0.00563796 * \\
(0.0818)\end{array}$ & & \\
\hline $\begin{array}{l}\text { SUMMER } \\
(\text { EAST })(-2)\end{array}$ & $\begin{array}{c}-0.0284997 * * \\
(0.0260)\end{array}$ & & & $\begin{array}{c}-0.00994490^{* *} \\
(0.0117)\end{array}$ & $\begin{array}{c}-0.00471687^{*} \\
(0.0942)\end{array}$ & $\begin{array}{l}-0.00450155^{* * *} \\
(0.0066)\end{array}$ & $\begin{array}{c}-0.00413973 * * * \\
(0.0082)\end{array}$ \\
\hline SPRING RAINFALL & & & & $0.00506002 *(0.0604)$ & & $0.003426 * * *(0.002)$ & \\
\hline SPRING RAINFALL (-1) & & & & & $-0.0069188 * * *(0.0042)$ & $0.0016134 *(0.0996)$ & \\
\hline SPRING RAINFALL (-2) & & & & $0.009358 * * *(0.0002)$ & & $0.00371 * * *(0.0009)$ & \\
\hline$R^{2}$ & 0.58 & 0.19 & 0.37 & 0.51 & 0.36 & 0.43 & 0.67 \\
\hline$F$ & 12.32 & 9.05 & 5.05 & 12.58 & 4.99 & 6.62 & 11.38 \\
\hline
\end{tabular}
contrast and trend with a delay). The linear function form is accepted except in Model 2 (Reset Test). All series are homoclassic except for Model 2 (White and Breusch-Pagan Tests) and there are no multicollinearity problems $(\mathrm{VIF})$ 
Table 4. Evaluation of the impact of climate and demographics on the labour market and daily wages. England, 1659-1740. In brackets, whether the relationship was direct $(+)$ or inverse $(-)$.

Independent Variables

\begin{tabular}{lccccc}
\hline \multicolumn{1}{c}{$\begin{array}{c}\text { Dependent } \\
\text { Variables }\end{array}$} & $\begin{array}{c}\text { CLIMATE } \\
(\mathbf{I})\end{array}$ & $\begin{array}{c}\text { POPULATIO } \\
\text { N (II) }\end{array}$ & $\begin{array}{c}\text { OTHER DEMOGR } \\
\text { (III) }\end{array}$ & I+II & I+III \\
\hline $\begin{array}{l}\text { REAL FARM } \\
\text { WAGES }\end{array}$ & $34 \%(+)$ & $0 \%$ & $34 \%(+)$ & $46 \%(+)$ & $61 \%(+)$ \\
\hline $\begin{array}{l}\text { FARM } \\
\text { WAGES }\end{array}$ & $17 \%(+)$ & $0 \%$ & $0 \%$ & $17 \%(+)$ & $17 \%(+)$ \\
\hline $\begin{array}{l}\text { CRAFT } \\
\text { WAGES }\end{array}$ & $61 \%(+)$ & $60 \%(+)$ & $68 \%(+)$ & $68 \%(+)$ & $68 \%(+)$ \\
\hline
\end{tabular}

Source: authors' own data using MCO method. * level of significance at $10 \%, * *=$ level of significance at $5 \%, * * *=$ level of significance at $1 \%$. The percentage indicates the coefficients of determination for each model. The Snedecor F contrast is correct in all cases and there is no multicollinearity or heterocedasticity. The CLIMATE series are Manley temperatures, volcanic activity from Mann et al, summer rainfall from Rinne et al., OTHER DEMOGR correspond to the mortality and birth series by Wrigley et al. 
Table 5. Contrast in the response of real GDP to temperatures, volcanic dust and rainfall, England, 1661-1740.

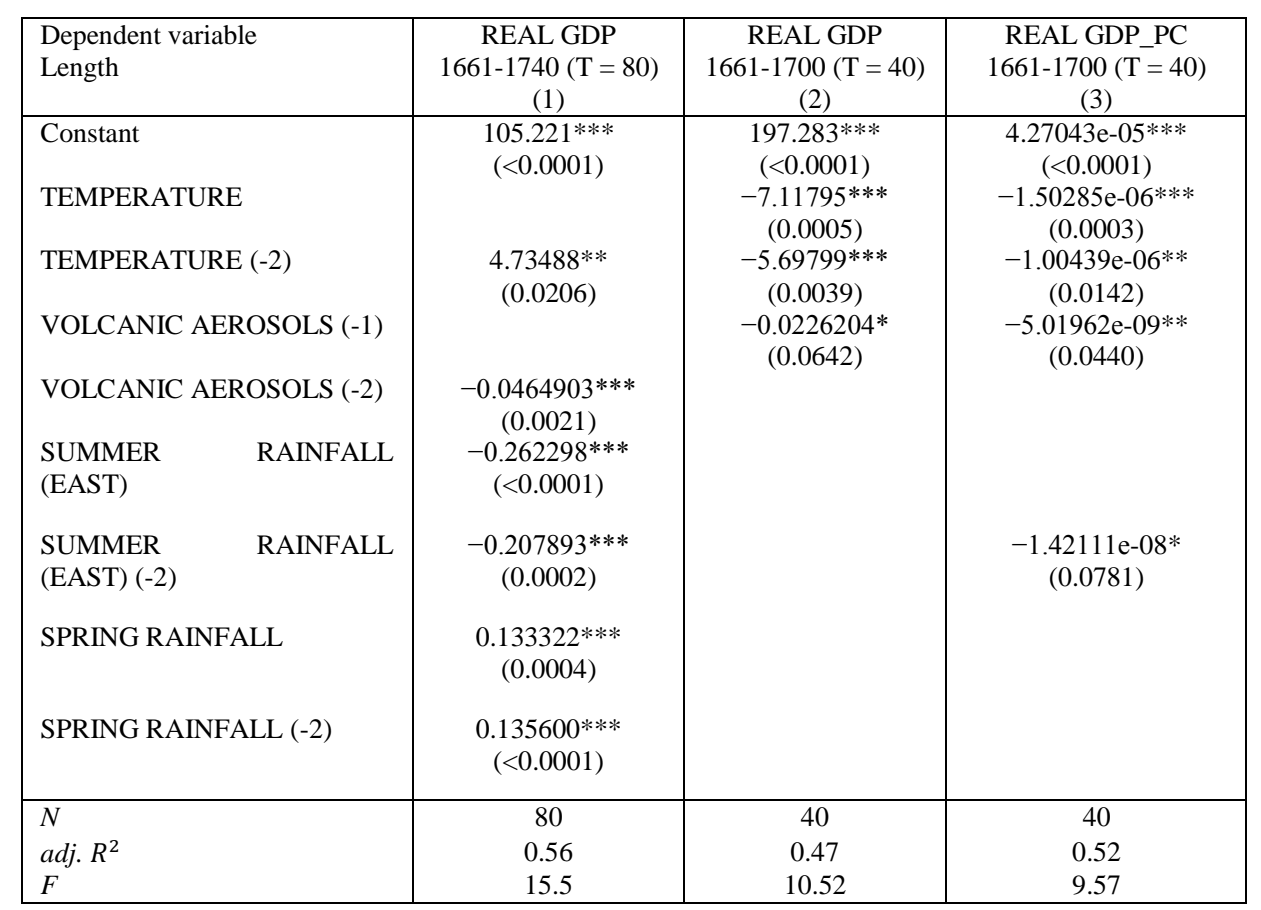

Source: authors' own data using MCO method. $*=$ level of significance at $10 \%, * *=$ level of significance at $5 \%$, *** = level of significance at $1 \%$. REAL GDP and REAL GDP_PC are stationary according to the ADF Test, in contrast and trend with six delays, but the correlogram indicates that they are not stationary. The rest of the variables are stationary. The linear functional form is accepted except in Model 2 (Test Reset), but if we reformulate the model with squares (non-linear form) the results are similar. No series present problems with heterocedasticity (White and Breusch-Pagan Tests), or multicollinearity (VIF), and the errors follow a normal distribution. 